\title{
LARGE-SCALE VEGETATIVE PROPAGATION OF LASIOCOCCA COMBERI BY AIR LAYERING
}

\author{
Kamila PK \& Panda PC* \\ Taxonomy and Conservation Division, Regional Plant Resource Centre, Bhubaneswar-751015, Odisha, India \\ pcpanda2001@yahoo.co.in \\ Received February 2018; accepted July 2018
}

\begin{abstract}
Lasiococca comberi (Euphorbiaceae), a threatened forest tree species of Eastern Ghats of India, has inherent problems of seed germination and seedling establishment in nature. To overcome this problem and to facilitate large-scale production of planting materials for reintroduction programmes to augment the wild populations of this threatened species, an attempt has been made to develop an efficient vegetative propagation method through air layering. Three types of auxins such as indole-3-butyric acid (IBA), indole acetic acid (IAA) and naphthalene acetic acid (NAA) in different concentrations and combinations were used to induce rooting in stems of healthy mature trees in forests during rainy season. Air-layered branches treated with $5000 \mathrm{ppm}$ IBA resulted in maximum percentage of rooting $(95.23 \pm 7.6 \%)$, maximum number $(14.50 \pm 1.9)$ and length of roots $(12.5 \pm 1.0 \mathrm{~cm})$, minimum days taken for root initiation $(18.5 \pm 0.5$ days $)$ and highest percentage of survival of air-layered propagules. The well-rooted branches were transplanted in polybags under mist house conditions for acclimatisation and hardening before field planting. The result of the present study can be useful for mass production of large-sized planting materials of this threatened species from mature trees in a relatively shorter period at a reasonable cost for reintroduction to natural habitats as a part of species recovery programme.
\end{abstract}

Keywords: Eastern Ghats, indole-3-butyric acid (IBA), mass production, propagules, reintroduction, threatened species

\section{INTRODUCTION}

Lasiococca comberi (Euphorbiaceae), a moderatesized evergreen tree, grows wild in the forests of Odisha (Khurda and Mayurbhanj districts) and Andhra Pradesh (Vishakhapatnam and East Godavari districts), India (Haines 1921) and in Thailand (Welzen 2007). This species has been listed as a threatened taxon in the IUCN Red List of Threatened Plants (Walter \& Gillett 1998). The natural occurrence of the species is mostly confined to deep ravines and hill slopes close to streams in damp forests and it can easily be identified from a distance by its characteristic whitish-grey fissured trunks. The leaves are opposite or subverticillate, elliptic-lanceolate or panduriform, cordate or subcordate at the base, acute to caudate acuminate at the apex. Flowers are dioecious; male flowers are borne in elongated drooping racemes from lower leaf axils and female flowers from the axils of terminal leaves. Fruits are trilobed, covered with conical tubercles; seeds are globose, deep brown, endosperm white and oily in nature. The plant flowers in the months of March-June and the fruits mature in August-October (Haines 1921). The seeds of $L$. comberi are an important source of oil $(41.5 \%)$ with high amount of unsaturated fatty acids $(87.6 \%)$. The predominant fatty acids are linolenic acid $(65.3 \%)$, oleic acid $(13.8 \%)$, linoleic acid $(7.1 \%)$, palmitic acid $(5.3 \%)$ and stearic acid $(3.1 \%)$. The seed oil is also rich in protein, crude fibre and carbohydrate (Kamila et al. 2017). The wood is very strong, durable, termite-proof and is used for making agricultural implements, walking sticks and also used as firewood by the local people. Monkeys, squirrels, birds, ants and rodents consume the mature seeds of L. comberi.

As the case with other threatened plant species, genetic variability is desirable for long-term survival of the species and this can be accomplished through seed propagation. However, propagation of $L$. comberi from seeds has inherent biological problems largely due to unequal distribution of male and female 
flowers, irregular seed setting, recalcitrant nature of seeds, poor seed germination and seedling establishment in natural habitats. Conventional vegetative propagation through rooting of stem cuttings is not always successful. Propagation through air layering was attempted as an alternative tool to seed propagation and vegetative propagation by rooting of cuttings. This will allow large-scale production of planting materials for reintroduction programmes. Currently, there is no published report on standardisation of any propagation method of $L$. comberi. In the present study, an experiment was conducted to examine the rooting response of air-layered branches of L. comberi towards different types and doses of root-promoting phytohormones. Rooting was induced in air-layered branches treated with varying concentrations and combinations of natural and synthetic auxins, namely, indole-3acetic acid (IAA), indole-3-buttyric acid (IBA) and naphthalene acetic acid (NAA). Synergistic effect of mixtures of two components of auxins on root induction in air layers was recorded. The findings of the study would provide a cost effective technique for mass production of mature and true-to-type planting materials for reintroduction in natural and near natural habitats. This would ensure long-term survival of self sustaining and viable population of this species in the wild.

\section{MATERIALS AND METHODS}

\section{Study site and selection of mother plants}

A total of 63 mature, healthy and disease-free trees of $L$. comberi occurring in three isolated natural stands (21 each) in Aranga Reserved Forest (RF) $\left(19^{\circ} 54^{\prime} \mathrm{N}, 85^{\circ} 08^{\prime} \mathrm{E}, 109 \mathrm{~m}\right.$ above sea level (m asl)), Tamana RF $\left(19^{\circ} 52^{\prime} \mathrm{N}, 85^{\circ} 03^{\prime} \mathrm{E}\right.$, $152 \mathrm{~m}$ asl) and Rajin RF (19 $52^{\prime} \mathrm{N}, 85^{\circ} 01^{\prime} \mathrm{E}$, $170 \mathrm{~m}$ asl) of Balugaon Range, Khurda Forest Division, Odisha, India were selected as mother trees for air-layering experiments. The trees had active vegetative growth and had no visual symptoms of nutritional deficiencies or diseases.

\section{Experimental design and treatment}

The present experiment was designed to evaluate the effect of type, concentration and combination of root promoting hormones at which rooting can be induced with best results. The experiments were carried out in a completely randomised block design and repeated thrice. A total of 21 trees of each of the three natural stands served as three replicates. Air layering was done in the monsoon season (July-October 2015) to take benefit of active growth phase of the plant and relatively high humidity which are known to be ideal conditions for rooting (Loach 1988). Effectiveness of natural and synthetic auxins (IBA, IAA and NAA) were tested in different concentrations $(1000,2500,5000,7500$ and $10,000 \mathrm{ppm}$ ) and combinations to determine the existence of synergistic effects in rooting behaviour of air-layered branches. Control set was treated using double distilled water. All auxins were prepared in liquid form by dissolving in $70 \%$ ethyl alcohol which was later diluted with double distilled water. For smooth application of hormones on the stem, auxins were mixed with inert talcum powder and made into a paste.

In each tree, 22 stems of desired characteristics were treated with different types and concentrations of rooting hormone (21 auxin treatments +1 control). Stems of actively growing branches measuring about $30-50 \mathrm{~cm}$ in length, $1-2 \mathrm{~cm}$ in diameter and with 20-30 leaves from the lower canopy of each tree were randomly selected for exogenous hormonal treatment. Small circular strips of bark $(2 \mathrm{~cm})$ were girdled out carefully just below the nodes of lateral branches using a sharp budding knife without injuring the underlying wood. The exposed girdled portions of the stems were then treated with different concentrations of auxin paste. The cut surfaces were covered with moistened sphagnum moss treated with $0.1 \%$ aqueous solution of fungicide bavistine and wrapped in $170 \mu \mathrm{m}$ thick transparent polythene strips and tied at both ends.

\section{Data collection}

The air-layered branches were left undisturbed on the parent plants for about 10 weeks to allow for root initiation. During this period, the branches were sprayed with water every 2 days if there was no rain; and inspected at weekly intervals for evidence of root emergence. After 10 weeks, rooted branches were detached from the parent plants using a pair of secateurs. Sphagnum mosses were removed gently, washed with double distilled water and assessed for rooting success. Rooting percentage, root numbers and root 
lengths were recorded. The length of primary roots were measured from base to the tips with a measuring scale and mean root length was calculated after taking measurement of roots in each replication. The number of roots per air-layered branch was counted and the average value determined. Rooted air layers were then planted in polythene bags (10 inch $\times 8$ inch) containing soil, sand and farm yard manure mixture (FYM) in 1:1:1 ratio in mist house condition for acclimatisation and hardening for 30 days followed by transfer to polybags in open nursery. After 3 months, the living plants were counted and percentage of survival was calculated.

\section{Statistical analysis of data}

Mean values of all treatments were subjected to analysis of variance (ANOVA) at the level of significance of $p<0.05$. Mean values were calculated using Duncan's multiple range test.

\section{RESULTS AND DISCUSSION}

In the present study, the effect of exogenous auxins on root induction in air-layered branches of L. comberi was investigated (Figure 1). Air-layered branches showed an initial callus formation at the edges of the removed bark ring. Root initiation
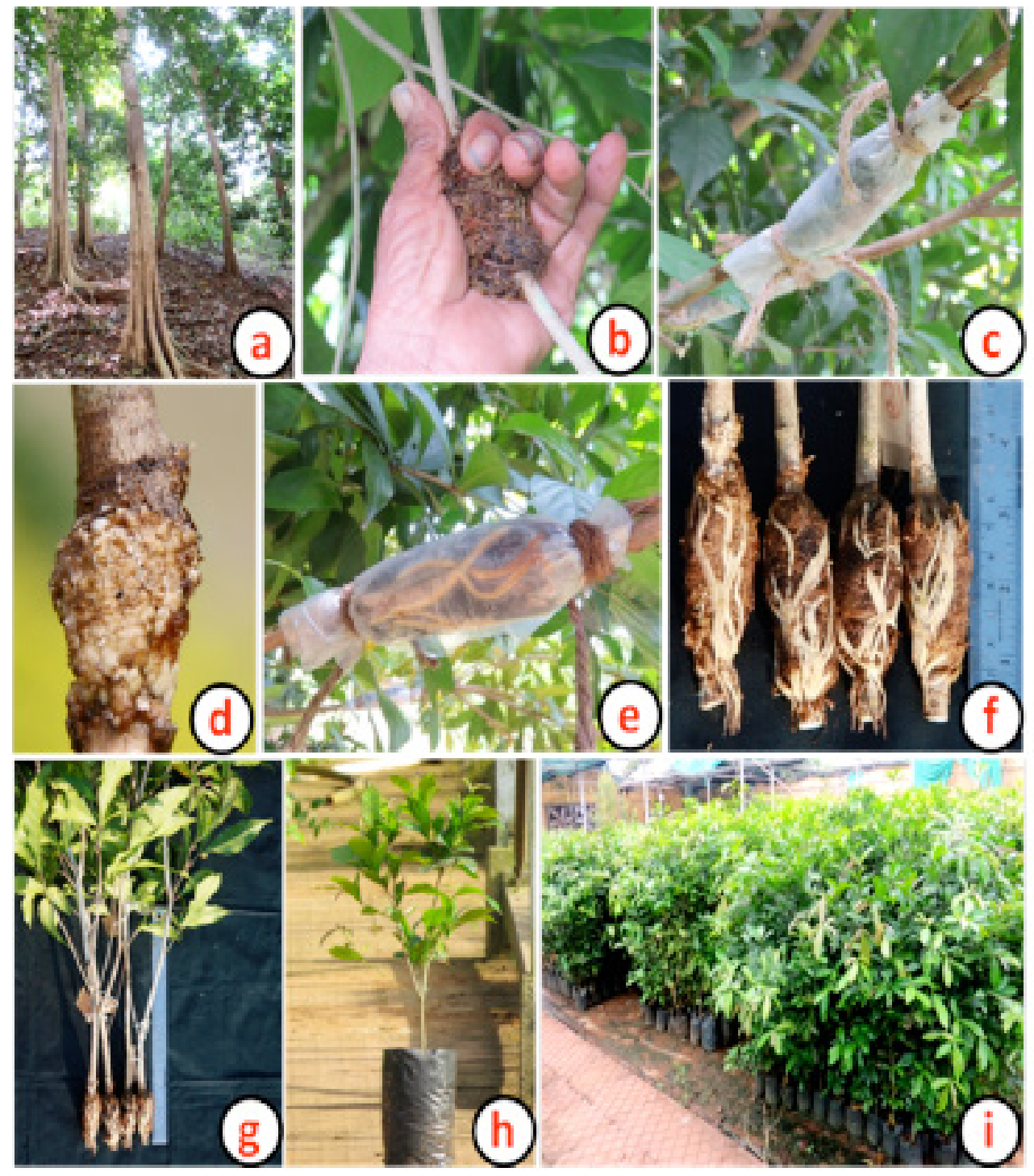

Figure 1 Propagation through rooting in air-layering shoots of Lasiococca comberi;(a) natural population of L. comberi, (b) use of sphagnum moss as rooting medium at girdled portion of stem, (c) air-layered branch, (d) callus formation at the basal portion of air-layered branch treated with $7500 \mathrm{ppm}$ IAA,

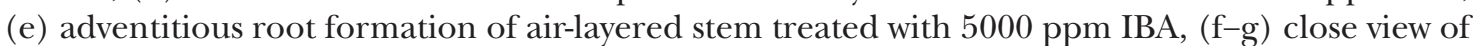
rooting in branches treated with 5000 ppm IBA, (h) rooted air-layered stem after being transplanted to polybags, and (i) stock plants propagated through air-layering maintained in nursery 
was first observed in auxin-treated air-layered branches. There was no sign of callus formation in the control after two weeks of observation. By 10 weeks, there were significant differences $(\mathrm{p}<0.05)$ between the three auxin treatments, i.e. IBA $>$ NAA > IAA (Table 1). Among the single treatments, 5000 ppm IBA induced rooting in maximum number of branches $(95.23 \pm 7.6 \%)$, followed by 2500 ppm NAA $(85.71 \pm 5.0 \%)$ and $7500 \mathrm{ppm}$ IAA $(76.19 \pm 2.1 \%)$. IBA at $5000 \mathrm{ppm}$ increased the mean number of roots formed by six-fold, mean root length by nine-fold and survival rate by five-fold compared with control (Table 1). Maximum rooting percentage was also achieved using IBA $5000 \mathrm{ppm}$ in other plant species such as Litchi chinensis (Chawla et al. 2012) and Picconia azorica (Martins et al. 2011). In Blighia sapida, a concentration of $3500 \mathrm{ppm}$ of IBA was found to be most effective for root induction in air-layered stems (Maurya et al. 2013). Treatment with IBA promoted root formation in the air-layered branches of Fagraea auriculatum, a critically endangered species of Singapore (Yeo et al. 2011). Auxin is a very effective rooting agent for many difficult-toroot species (Davis 1988) and recommended for general use because of its non-toxic nature to plants over a wide range of concentrations compared with NAA or IAA (Hartmann et al. 2010).

Several combinations and concentrations of IBA, NAA and IBA were also investigated to assess their synergistic effects in stimulating rhizogenesis in L. comberi air-layered branches. With the mixture of two auxins, rooting percentage increased in all combinations at lower concentrations compared with individual growth hormone and control. Similar synergistic

Table 1 Effects of different concentrations of auxins on rooting percentage, number and length of roots and survival percentage of air-layered branches of Lasiococca comberi after 10 weeks

\begin{tabular}{|c|c|c|c|c|c|c|c|}
\hline \multicolumn{3}{|c|}{ Auxin (ppm) } & \multirow{2}{*}{$\begin{array}{l}\text { Mean days for } \\
\text { root initiation }\end{array}$} & \multirow{2}{*}{$\begin{array}{l}\text { Rooting } \\
\quad(\%)\end{array}$} & \multirow[t]{2}{*}{ No. of roots } & \multirow{2}{*}{$\begin{array}{l}\text { Mean root } \\
\text { length }(\mathrm{cm})\end{array}$} & \multirow{2}{*}{$\begin{array}{c}\text { Survival }(\%) \\
\text { in nursery }\end{array}$} \\
\hline IBA & IAA & $\mathrm{NAA}$ & & & & & \\
\hline 0 & 0 & 0 & $48.20 \pm 6.0^{\mathrm{a}}$ & $23.80 \pm 0.2^{\mathrm{s}}$ & $2.20 \pm 0.2^{\mathrm{s}-\mathrm{u}}$ & $1.3 \pm 0.08^{\mathrm{r}}$ & $20^{\mathrm{v}}$ \\
\hline 1000 & - & - & $34.73 \pm 2.3^{\mathrm{d}-\mathrm{h}}$ & $71.42 \pm 3.3^{\mathrm{g}-\mathrm{j}}$ & $6.60 \pm 0.5^{\mathrm{g}-\mathrm{m}}$ & $5.8 \pm 0.3^{\mathrm{hi}}$ & $72.22^{\mathrm{lm}}$ \\
\hline 2500 & - & - & $29.56 \pm 1.1^{j-q}$ & $80.95 \pm 4.0^{c-f}$ & $9.29 \pm 1.1^{\mathrm{bc}}$ & $9.0 \pm 0.5^{\mathrm{bc}}$ & $89.47^{\mathrm{d}-\mathrm{f}}$ \\
\hline 5000 & - & - & $18.50 \pm 0.5^{\mathrm{v}}$ & $95.23 \pm 7.6^{\mathrm{a}}$ & $14.50 \pm 1.9^{\mathrm{a}}$ & $12.5 \pm 1.0^{\mathrm{a}}$ & $100^{\mathrm{a}}$ \\
\hline 7500 & - & - & $25.58 \pm 1.0^{\mathrm{r}-\mathrm{t}}$ & $73.01 \pm 2.9^{g-i}$ & $8.58 \pm 1.0^{\mathrm{b}-\mathrm{e}}$ & $6.5 \pm 0.4^{\mathrm{f}-\mathrm{h}}$ & $78.26^{j}$ \\
\hline 10,000 & - & - & $31.38 \pm 2.0^{\mathrm{h}-\mathrm{o}}$ & $57.14 \pm 2.6^{\mathrm{mn}}$ & $4.80 \pm 0.5^{\mathrm{o}-\mathrm{q}}$ & $5.0 \pm 0.4^{\mathrm{i}-\mathrm{m}}$ & $52.77^{\mathrm{st}}$ \\
\hline- & 1000 & - & $39.45 \pm 2.0^{\mathrm{b}}$ & $38.09 \pm 0.9^{r}$ & $3.37 \pm 0.3^{\mathrm{q}-\mathrm{t}}$ & $4.7 \pm 0.3^{\mathrm{j}-\mathrm{o}}$ & $54.16^{\mathrm{s}}$ \\
\hline- & 2500 & - & $37.21 \pm 2.2^{\mathrm{b}-\mathrm{f}}$ & $52.38 \pm 1.1^{\mathrm{no}}$ & $6.93 \pm 0.6^{\mathrm{e}-\mathrm{k}}$ & $5.0 \pm 0.4^{\mathrm{i}-\mathrm{m}}$ & $69.69^{\mathrm{n}}$ \\
\hline- & 5000 & - & $32.10 \pm 1.9^{\mathrm{h}-\mathrm{n}}$ & $61.90 \pm 1.9^{\mathrm{k}-\mathrm{m}}$ & $7.92 \pm 0.5^{\mathrm{b}-\mathrm{i}}$ & $7.8 \pm 0.6^{\mathrm{de}}$ & $92.30^{\mathrm{b}-\mathrm{d}}$ \\
\hline- & 7500 & - & $39.41 \pm 2.5^{\mathrm{bc}}$ & $76.19 \pm 2.1^{\mathrm{e}-\mathrm{h}}$ & $8.37 \pm 1.0^{\mathrm{b}-\mathrm{f}}$ & $8.5 \pm 0.6^{\mathrm{cd}}$ & $93.75^{\mathrm{bc}}$ \\
\hline- & 10,000 & - & $38.40 \pm 2.3^{\mathrm{b}-\mathrm{d}}$ & $42.85 \pm 1.0^{\mathrm{pq}}$ & $4.18 \pm 0.3^{\mathrm{qr}}$ & $5.1 \pm 0.2^{\mathrm{i}-1}$ & $74.07^{\mathrm{kl}}$ \\
\hline- & - & 1000 & $37.12 \pm 1.0^{\mathrm{b}-\mathrm{g}}$ & $61.90 \pm 1.5^{\mathrm{k}-\mathrm{m}}$ & $5.89 \pm 0.7^{\mathrm{i}-\mathrm{p}}$ & $3.5 \pm 0.2^{\mathrm{p}}$ & $64.10^{\mathrm{o}-\mathrm{q}}$ \\
\hline- & - & 2500 & $25.64 \pm 1.0^{\mathrm{r}-\mathrm{u}}$ & $85.71 \pm 5.0^{\mathrm{b}-\mathrm{d}}$ & $9.46 \pm 1.2^{\mathrm{b}}$ & $9.6 \pm 0.8^{\mathrm{b}}$ & $94.44^{\mathrm{b}}$ \\
\hline- & - & 5000 & $33.33 \pm 1.1^{\mathrm{e}-\mathrm{j}}$ & $71.42 \pm 1.4^{\mathrm{g}-\mathrm{j}}$ & $9.04 \pm 1.0^{\mathrm{b}-\mathrm{d}}$ & $7.0 \pm 0.5^{\mathrm{e}-\mathrm{g}}$ & $82.22^{\mathrm{g}-\mathrm{i}}$ \\
\hline- & - & 7500 & $37.26 \pm 1.4^{\mathrm{b}-\mathrm{e}}$ & $66.66 \pm 2.0^{\mathrm{i}-1}$ & $8.00 \pm 1.0^{\mathrm{b}-\mathrm{h}}$ & $5.5 \pm 0.3^{\mathrm{ij}}$ & $76.19^{j \mathrm{k}}$ \\
\hline- & - & 10,000 & $32.56 \pm 2.1^{\mathrm{h}-1}$ & $47.61 \pm 1.4^{\mathrm{op}}$ & $3.50 \pm 0.3^{\mathrm{q}-\mathrm{s}}$ & $2.3 \pm 0.1^{q}$ & $50.00^{\mathrm{u}}$ \\
\hline 1000 & 1000 & - & $32.97 \pm 2.0^{\mathrm{g}-\mathrm{k}}$ & $76.19 \pm 3.2^{\mathrm{e}-\mathrm{h}}$ & $6.50 \pm 0.5^{\mathrm{h}-\mathrm{n}}$ & $5.2 \pm 0.2^{\mathrm{i}-\mathrm{k}}$ & $62.5^{\mathrm{p}-\mathrm{r}}$ \\
\hline 2500 & 2500 & - & $28.00 \pm 1.5^{\mathrm{o}-\mathrm{r}}$ & $82.53 \pm 5.5^{\mathrm{b}-\mathrm{e}}$ & $7.59 \pm 0.6^{\mathrm{d}-\mathrm{j}}$ & $7.8 \pm 0.5^{\mathrm{de}}$ & $82.69^{g h}$ \\
\hline 1000 & - & 1000 & $30.00 \pm 1.8^{\mathrm{i}-\mathrm{o}}$ & $77.77 \pm 2.3^{\mathrm{e}-\mathrm{g}}$ & $6.89 \pm 0.5^{\mathrm{f}-\mathrm{l}}$ & $4.9 \pm 0.1^{\mathrm{i}-\mathrm{n}}$ & $65.30^{\circ}$ \\
\hline 2500 & - & 2500 & $27.98 \pm 1.5^{\mathrm{o}-\mathrm{s}}$ & $88.88 \pm 6.1^{\mathrm{ab}}$ & $8.23 \pm 1.0^{\mathrm{b}-\mathrm{g}}$ & $7.1 \pm 0.6^{\mathrm{ef}}$ & $91.07^{c-e}$ \\
\hline- & 1000 & 1000 & $34.11 \pm 1.0^{\mathrm{e}-\mathrm{i}}$ & $68.25 \pm 2.6^{\mathrm{i}-\mathrm{k}}$ & $6.30 \pm 0.4^{\mathrm{i}-\mathrm{o}}$ & $5.0 \pm 0.2^{\mathrm{i}-\mathrm{m}}$ & $65.11^{\mathrm{op}}$ \\
\hline- & 2500 & 2500 & $32.43 \pm 1.8^{\mathrm{h}-\mathrm{m}}$ & $87.30 \pm 4.4^{\mathrm{bc}}$ & $7.92 \pm 0.6^{\mathrm{b}-\mathrm{i}}$ & $6.5 \pm 0.6^{\mathrm{f}-\mathrm{h}}$ & $85.45^{\mathrm{g}}$ \\
\hline
\end{tabular}

In a column, different letters in superscripts indicate statistically significant difference between the means $(\mathrm{p}<0.05)$ as determined by Duncan's new multiple range test 
effects on rooting have been reported in some mangrove species such as Heritiera fomes, Intsia bijuga and Excoecaria agallocha (Eganathan et al. 2000).

The relatively poor rooting percentage in IAAtreated branches of $L$. comberi in comparison with IBA could be explained by the photosensitive nature of the former auxin (Hartmann et al. 2010). IBA is less sensitive to non-biological degradation such as photo-oxidation (Epstein \& Ludwig-Muller 1993). Differences in uptake and metabolism of the two auxins may be a cause for difference in rooting behaviour (Krisantini et al. 2006).

In this study, $5000 \mathrm{ppm}$ IBA, $7500 \mathrm{ppm}$ IAA and 2500 ppm NAA applied singly were found to be the optimum concentrations for best rooting in $L$. comberi stems. The rest of the concentrations reduced rooting ability of the air-layered branches (Table 1). Similar trends in rooting have been reported in Myrica esculenta (Chaukiyal 2015) and Drypetes malabarica (Jose et al. 2015). Lower concentration of auxin is reported to be effective for formation of adventitious root in Quercus serrata (Srivastava et al. 2000). The hormone concentration for best result in air layering depends on several factors such as difference in species, altitude, agro-climatic conditions (Chaukiyal 2015), stage of development of the plant, location in the branch where rooting will be induced, carbon/ nitrogen ratio, environmental factors, time of execution as well as the substrate used (Barbosa et al. 1993). The successful adventitious root formation and the subsequent developments are also highly dependent on interaction between endogenous and exogenous auxins (Kochhar et al. 2005). An important factor that promotes rooting is the ability of branches to accumulate carbohydrates and auxins from the leaves and the shoot tips. The method of girdling during air layering stimulates mobilisation of carbohydrates and auxins which accumulate in the basal portion of girdled branches. These added food reserves favour the formation of callus, development of adventitious root primordia and subsequent root formation (Adriance \& Brison 1955, Hartmann et al. 2010) .

The minimum time $(18.5 \pm 0.5$ days $)$ for root initiation in $L$. comberi was observed with treatment of IBA at $5000 \mathrm{ppm}$ followed by 7500 ppm NAA (25.64 \pm 1.0 days) compared with control $(48.20 \pm 6.0$ days) (Table 1$)$. In general, various classes of growth regulators (e.g. auxins, cytokinins, gibberellins and ethylene) and inhibitors (e.g. abscisic acid) influence root initiation. Of these, IBA and NAA facilitate root formation in air layers in a relatively short period of time (Bose et al. 1986). IBA treatment may have significant role in early rise in rootinducing cofactor and decrease in the level of root-initiating inhibitors, leading to early rooting (Nanda 1975).

Survival percentage of $L$. comberi rooted air layers in field condition was as low as $20 \%$ in untreated branches but with treatment of 5000 ppm IBA, survival was $100 \%$. Although the use of air layering depends on the availability of the number of branches in natural tree stands, it could effectively complement sexual propagation from seeds to rapidly augment wild populations. In the case of $L$. comberi, air-layering method proved useful in mass production of large-sized, genetically uniform planting materials for reintroduction to natural habitats in forests and for ex-situ conservation in botanic gardens, conservatories and experimental plots. Saplings produced through air layering are more adaptable in field conditions as they are obtained from mature trees which have experienced both biotic and abiotic stresses in the past (Eganathan et al. 2000). The reintroduction of this threatened species is expected to ensure long-term survival of the species by avoiding the loss of genetic diversity associated with very small local populations, which are more susceptible to environmental and demographic stochasticity (Martins et al. 2011).

\section{CONCLUSIONS}

The results of the experiment indicated that the threatened plant species $L$. comberi is amenable to vegetative propagation by air layering. This technique can be effectively used to propagate this species in large numbers in the absence of any other alternative method such as seed germination and vegetative propagation by rooting of cuttings. Rooting in air layers of this species could be achieved in 10 weeks' time with optimal application of $5000 \mathrm{ppm}$ of IBA. This technique provides an efficient and cost-effective method for production of large-sized, ready-toplant saplings by bypassing the juvenile phase of development for reintroduction to natural habitats in forests. 


\section{ACKNOWLEDGEMENTS}

Authors are thankful to the Department of Biotechnology, Government of India for financial assistance under the project 'Preventing extinction and improving conservation status of threatened plants through application of biotechnological tools' (BT/Env/BC/01/2010). Thanks are due to the Chief Executive, Regional Plant Resource Centre, Bhubaneswar for providing laboratory and field facilities and to the Divisional Forest Officer, Khurda Forest Division for help and support during fieldwork.

\section{REFERENCES}

AdrIANCE GW \& BRISON FR. 1955. Propagation of Horticultural Plants. Tata McGraw-Hill Publishing Company Ltd, New Delhi.

Barbosa KM, Guedes FC, Guedes FA, Lima PS \& Lima JJ. 1993. Efeito do substrato no enraizamento de alporques do Uruzeiro. Pesquisa Agropecuaria Brasileira 28: 101-106.

Bose TK, Mitra SK \& SAdHu MK. 1986. Propagation of Tropical and Subtropical Horticultural Crops. Naya Prokash, Calcutta.

Chaukiyal SP. 2015. Vegetative propagation studies in Myrica esculenta (Kafal) - a non-legume nitrogen fixing species. Indian Journal of Forestry 38: 39-42.

Chawla W, Mehta K \& Chauhan N. 2012. Influence of plant growth regulators on rooting of litchi (Litchi chinensis Sonn.) air layers. The Asian Journal of Horticulture 7: 160-164.

DAvis TD. 1988. Photosynthesis during adventitious rooting. Pp 30-43 in Davis TD et al. (eds) Adventitious Root Formation in Cuttings. Dioscorides Press, Portland.

Eganathan P, SRinivasa RC \& Anand A. 2000. Vegetative propagation of three mangrove tree species by cuttings and air layering. Wetlands Ecology and Management 8 : 281-286. doi: 10.1023/A:1008481222718.

Epstein E, Ludwig-Muller J. 1993. Indole-3-butyric acid in plants: occurrence, synthesis, metabolism and transport. Physiologia Plantarum 88: 382-389. https:// doi.org/10.1111/j.1399-3054.1993.tb05513.x.

HaInEs HH. 1921. The Botany of Bihar and Odisha. Adlard and Son and West Newman Ltd, London.
Hartmann HT, Kester DE, Davies FT \& Geneve RL. 2010. Hartmann and Kester's Plant Propagation: Principles and Practices. Prentice-Hall, Upper Saddle River.

Jose PA, Sumod M \& VARGHese TK. 2015. Clonal propagation of Drypetes malabarica (Bedd.) Airy Shaw-an endemic and endangered tree of southern Western Ghats. Indian Journal of Forestry 38: 35-38.

Kamila PK, Ray A, Sahoo A, Nayak S, Mohapatra PK \& PANDA PC. 2017. Physicochemical characteristics of the Lasiococca comberi Haines seeds. Natural Product Research 32: 739-742. https://doi.org/10.1080/147 86419.2017.1408091.

KochHar VK, Singh SP, Katiyar RS \& Pushpangadan P. 2005. Differential rooting and sprouting behaviour of two Jatropha species and associated physiological and biochemical changes. Current Science 89: 936-939.

Krisantini S, Johnston M, Williams RR \& Beveridge C. 2006. Adventitious root formation in Grevillea (Proteaceae), an Australian native species. Scientia Horticulturae 107: 171-175. doi: 10.1016/j.scienta.2005.05.015.

LOACH K. 1988. Controlling environmental conditions to improve adventitious rooting. Pp 132-149 in Davis TD et al. (eds) Adventitious Root Formation in Cuttings. Dioscorides Press, Portland.

Martins J, Moreira O, Silva L \& Moura M. 2011. Vegetative propagation of the endangered Azorean tree, Picconia azorica. Arquipelago Life and Marine Sciences 28: 39-46.

Maurya RP, Lewis DM \& Chandler JefF st A. 2013. Studies on the propagation of Jamaican Ackee (Blighia sapida) by air layering. HortScience 48: 1298-1300.

NANDA KK. 1975. Physiology of adventitious root formation. Indian Journal of Plant Physiology 18: 80-90.

Srivastava PK, Singh TS \& Singh NI. 2000. Clonal propagation of Quercus serrata Thunb. syn. $Q$. acutissima Carr. through air layering. Indian Forester 126: 879-884.

Walter KS \& Gillett HJ (eds). 1998. 1997 lUCN Red List of Threatened Plants. Compiled by the World Conservation Monitoring Centre. IUCN-The World Conservation Union, Gland and Cambridge.

Welzen PC VAN. 2007. Euphorbiaceae (Genera G-Z). Pp 1-314 in Welzen PC van \& Chayamarit K (eds) Flora of Thailand. The Forest Herbarium, Bangkok.

Yeo CK, Ng BYQ, Ng PX et AL. 2011. Air layering: a suitable method for mass-propagating the nationally critically endangered Fagraea auriculatum Jack (Gentianaceae). Nature in Singapore 4: 383-392. 